\title{
Yak's Biochemistry Contain the Factors that Make it Possible for Human Habitation on the Top of the World in Central Asia
}

\author{
Lopa Basu and *Herbert W Ockerman \\ The Ohio State Ohio University, USA
}

Received: September 25, 2017; Published: October 11, 2017

*Corresponding author: : Herbert W Ockerman, Department of Animal and Food Sciences, Plumb Hall 230 A, 2027 Coffey Road, The Ohio State University, Columbus, OH 43210 USA

\begin{abstract}
The yak (Bos grunniens) fills the role of nutrition, fuel, leather and transportation of goods for inhabitants of this harsh environment. In fact, if nature had not created this animal, human life would be almost impossible for an extended period of time in this area of the world. Yaks are a major source of livelihood of the people living in the high altitude, cold weather parts of this planet.

Keywords: Yak; Hybrid; Meat; Dairy Products; Fuel; Leather; Transportation
\end{abstract}

\section{Introduction}

In English terminology, Yak is used for both sexes. In Himalayan terminology, Yak is used for the male and Dzomo or Zhom for the female (Figure 1).

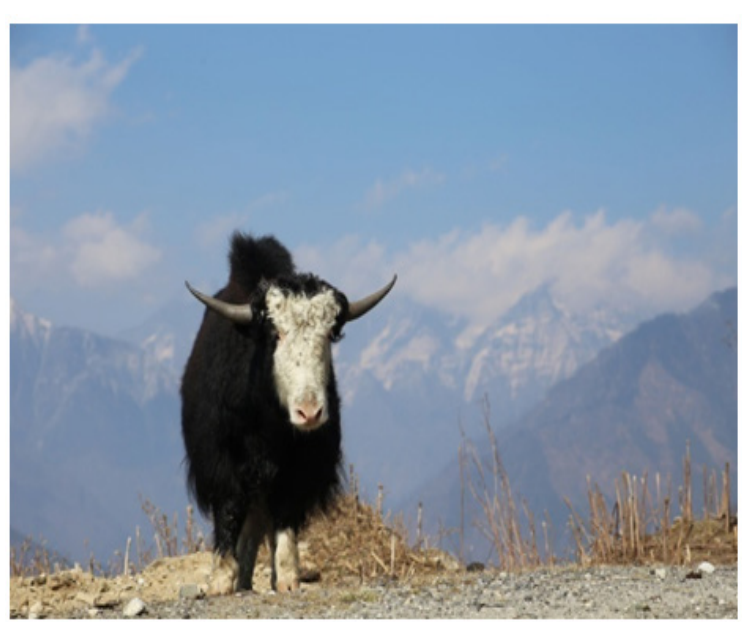

Figure 1: Wild Yak, Himalayas (Photographed by Lopa Basu).

\section{Materials and Methods}

\section{Description}

The yak have enlarged lungs (four times as large as cattle), and more numerous red blood cells (three times more than cattle) and smaller cells (1/2 the size of cattle). Yaks have a dense coat which may be red, brown or black. They also have long hair sometimes reaching the ground (kilts or skirt) and lower number of sweat glands for conserving heat. Strong solid horns are used for removing snow to obtain covered vegetation and also used to establish the pecking order. They have multiple stomachs ruminant for digesting cellulose and coarse grazing material. They are also divided into domesticated (smaller size) and wild (larger size) yak. When it gets too cold wild yaks migrate seasonally to the lower plains to eat grass, lichens' (composite symbiotic organism of algae and/or cyanobacteria living among multiple fungi) and herbs.

When it gets too hot they retreat to the higher plateau. Unfortunately, the numbers of these animals are decreasing due to uncontrolled hunting, predators, diseases, decreasing grazing areas and quality, malnutrition combined with the unforgiving environment. Yak nicknames are "Grunting Ox" or Hairy Cattle. The domesticated animals are Bos Grunniens and the wild is Bos mutus and they are native to the Himalayan Mountains of China Tibet, Nepal, and the surrounding areas. They were domesticated over 3,000 years ago, and can cross with bison and cattle. The male hybrids are sterile but the females (Dzomo or Zhom) are fertile. Yaks have short legs (females 4.5 feet in height and males 5.5-6.5 feet) with a weight of 1,800-2,200 pounds. If dairy cattle are used in the cross the milk production is increased but most owners prefer pure breeds. The yaks (both sexes) have large horns (30 inches), four compartment ruminant stomachs, and a shoulder hump. Yaks head droops before high massive shoulders. They are sure footed 
animals for the rough terrain. Thick red, black or brown undercoats acts as insulation and keep them warm to $-40^{\circ} \mathrm{F}$ or C. Domesticated yaks are more variable in color, and white splotches are common.

\section{Reproduction}

Heifers will breed at 18 months of age and gestation period is 8.5 months and males are of breeding age when then they are three years old. Calves at birth weigh about 30 pounds but grow quickly on mother's milk but the average survival rate is only about $50 \%$ due to poor nutrition for both mother and calf, harsh environmental conditions and death due to predators and diseases. Wild yak reproduce every two years and domestic yak sometimes reproduce ever year and occasionally have twins if the mothers have adequate nutrition. Infant yak can live up to 20 years.

\section{Social}

Most wild yak cows live in large herds with their young in groups of up to 100 or more animals. In contrast, adult males spend most of the year alone or in small groups.

\section{Uses Of Yak}

Meat - from grass fed animals is usually very lean and the yak is no exception.

Hair - When yaks shed their red, blackish or brown undercoat in the spring, the hair can be collected, combed out, and processed and results in a fiber that is comparable to cashmere, angora or qiviut (inner wool of the muskox). The coarser brown or black outer hair or 'guard hair' is traditionally used to weave ropes, belts, and bags.

Hides - Can be tanned and used for many leather products including tent material and leather clothing.

Horns and Bones - Are often carved into utensils or sold to tourists or shipped (often on this beast of burden) to more traveled areas. Bones also find domestic uses, are converted into jewelry or carved into art objectives. Horns are also carved into objects of art. Fuel- Dried dung of the yak is the only obtainable fuel in this area of the world and is sometime used as construction material.

\section{Yak Meat}

Yak meat is a staple and can be naturally frozen by the environment but drying is often used to increase shelf life. It is a sweet, juicy, ultra-lean dark red delicately flavored red meat that is not gamey. It is lighter tasting than beef and never greasy. Meat can be air-dried and will keep from one to two years. Smoked meat (bacon beef) requires one to two days in salt and then keeps for up to 2 years. Spiced jerky or curry jerky is also available. Vacuum packaging can reduce oxidation of yak meat during frozen storage.

\section{Meat Composition}

Only a few papers have addressed this topic but one of the more informant ones on yak meat is by XD Zi, GH Zhong [1-3]. The data in Figure 2 and Tables $1 \& 2$ is a summary from this source.

\section{Other Uses}

Beast of burden-Yak can transport salt, grain and etc. They are used for plowing and threshing grain (primarily barley). Some yaks can be saddled and ridden. Yak racing is also practiced along with yak skiing and yak polo. Milk - Yak cow milk (higher in butter fat than cows) makes excellent cheeses (chhurpi) and is often dried to increase shelf life. Butter which is consumed in large quantities is also used in lamps and made into butter sculptures used in religious festivities. Butter is a staple food with salt added. Sour buttermilk can also be added to milk to produce sour milk. Grain is sometimes added to milk which results in the main course meal. Milk-tea, a mixture of tea and milk is often served to guests and is yellow in color.

Milk and mushrooms are used to make a stew; salt is usually added but no additional sugar is needed since the milk is naturally sweet in flavor. Yogurt is produced which also contributes needed nutrition. Milk powder is just beginning to become popular. Renin is added to coagulate the milk to make cheese. Viscera (edible) includes heart, stomach plus ruminant, small and large intestine, liver, kidney. In the inedible category, lungs and pancreas are primarily used for dog feed even though they are considered edible in other areas of the world.

\section{Climate}

Yaks have been brought to warmer climates and placed in zoos and some can be found on ranches where their primary food is grass. Under these conditions their meat sells well since it is different and scarce but the animals seem to prefer a colder climate.

\section{Results and Discussion}

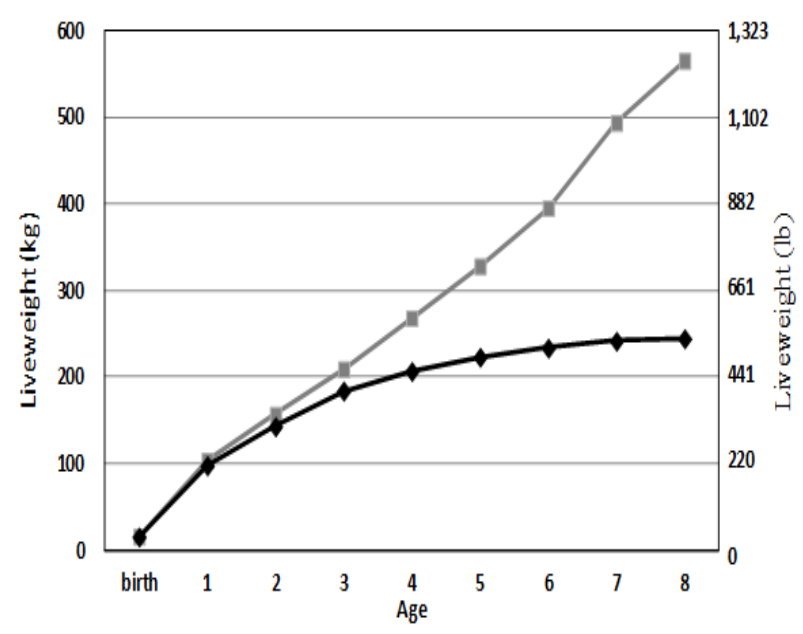

Figure 2: Live weights of Yak at different ages.

Shows the live weights of Yak at different ages. It is evident from this graph that both male and female yaks have similar birth weights but starting at age 2 and continuing through 8 years the males out gain the females and the final mature weight of the males is about twice as much as the females (Figure 2) and (Table 1). For dressing percentages, the bull and steer are not significantly different but the female has a significantly lower percentage. For back-fat thickness, comparing all the values the results indicate no significant difference due to sexes. Marbling scores indicate all sexes are significantly different with the steer having the highest amount 
followed by the bull and the female which had a significantly lower marbling score. For color, the steer had a significantly higher color values followed by similar scores for both bull and female.

For $\mathrm{pH}(1 \mathrm{~h})$, the steer and female had similar scores but the bull animals (Table 2).

Table 1: Carcass characteristics of Yak. was significantly higher. For pH (24h), all three sexes were similar but they are higher than would be expected for cattle suggesting that this may have been genetics or the animals may have been stressed before they were harvested. Also in general grass fed animals normally have higher ultimate $\mathrm{pH}$ values than grain fed

\begin{tabular}{|c|c|c|c|}
\hline \multirow{2}{*}{ Age } & Bull & Steer & Female \\
\cline { 2 - 4 } & $4.5-5.5(\mathrm{n}=11)$ & $4.5-5.5(\mathrm{n}=11)$ & $4.5(\mathrm{n}=7)$ \\
\hline Dressing, \% & $53.25 \pm 0.76 \mathrm{~b}$ & $55.04 \pm 0.52 \mathrm{~b}$ & $47.58 \pm 0.85 \mathrm{a}$ \\
\hline Backfat thickness, cm & $0.75 \pm 0.16 \mathrm{~b}$ & $0.58 \pm 0.10 \mathrm{~b}$ & $0.74 \pm 0.11 \mathrm{~b}$ \\
\hline Ribeye area, cm ${ }^{2}$ & $61.53 \pm 2.55 \mathrm{~b}$ & $68.56 \pm 3.76 \mathrm{~b}$ & $52.50 \pm 2.73 \mathrm{a}$ \\
\hline Marbling score of LD & $2.14 \pm 0.09 \mathrm{~b}$ & $2.39 \pm 0.03 \mathrm{c}$ & $1.75 \pm 0.13 \mathrm{a}$ \\
\hline Color & $3.53 \pm 0.02 \mathrm{a}$ & $3.79 \pm 0.03 \mathrm{~b}$ & $3.54 \pm 0.11 \mathrm{a}$ \\
\hline $\mathrm{pH}(1 \mathrm{~h})$ & $6.34 \pm 0.03 \mathrm{a}$ & $6.40 \pm 0.03 \mathrm{~b}$ & $6.48 \pm 0.03 \mathrm{~b}$ \\
\hline $\mathrm{pH}(24 \mathrm{~h})$ & $5.84 \pm 0.10 \mathrm{a}$ & $6.11 \pm 0.05 \mathrm{a}$ & $6.02 \pm 0.05 \mathrm{a}$ \\
\hline
\end{tabular}

*Mean values in a row with same letter in superscript are not significantly different.

Table 2: Proximate Composition of 10th/12th rib-cut of Yak.

\begin{tabular}{|c|c|c|c|}
\hline \multirow{2}{*}{ Age } & Bull & Steer & Female \\
\hline & 4.5-5.5 Age $(n=11)$ & 4.5-5.5 Age $(n=11)$ & 4.5 Age $(n=7)$ \\
\hline Dry matter \% & $26.54 \llbracket 0.20^{\mathrm{a}}$ & $29.71 \bowtie 1.03^{\mathrm{b}}$ & $31.93 \llbracket 0.69^{\mathrm{b}}$ \\
\hline Protein \% & $22.58 \llbracket 0.27^{\mathrm{a}}$ & $21.55 \llbracket 0.52^{\mathrm{a}}$ & $19.98 \bowtie 0.36^{\mathrm{b}}$ \\
\hline Fat $\%$ & $2.97 \rrbracket 0.33^{\mathrm{a}}$ & $7.26 \bowtie 1.43^{\mathrm{b}}$ & $10.86 \rrbracket 1.14^{\mathrm{b}}$ \\
\hline Ash \% & $1.00 \otimes 0.03^{\mathrm{a}}$ & $0.93 \bowtie 0.03^{\mathrm{a}}$ & $1.00 \otimes 0.06^{\mathrm{a}}$ \\
\hline
\end{tabular}

Proximate composition of 10th/12th rib-cut of Yak is shown in (Table 2). Present dry matter was significantly lower in bulls than in steers or females which were not significantly different. Percent protein was significantly lower in females than in bulls and steers which were not significantly different. Fat parentage was significantly lower in bulls than in steers or females which were not significantly different. Percent ash was not significantly different due to sex. Amino acids were also analyzed in the original research but values are not shown in this summarized version since most of the values were similar to the expected ranges. The only major difference was that methionine is dramatically lower $(0.34 \mathrm{~g} / 100$ g protein).

\section{Conclusion}

Yaks, due to their genetic construction have the ability to prosper at high altitudes and withstand stand cold temperatures and sparse vegetation. Their existence makes human habitation possible under these same conditions.

\section{References}

1. XD Zi, GH Zhong, YL Wen, JC Zhong, CL Liu, et al. (2003) Growth Performance, Carcass Composition and Meat Quality of Jiulong-yak (Bos grunniens). Asian-Aust. J. Anim. Sci. 2004 17(3): 410-414.

2. Basu L, Ockerman HW (2017) An Animal Designed for High Altitude and Cold Weather and Found on Top of the World in Central Asia. ICo MST.

3. S Tang, L Yan, SLi, L Wang (2017) Oxidation-Induced Structural Changes of Yak Myofibrillar Protein Under Different Packaging Conditions in Frozen Storage. ICo MST.

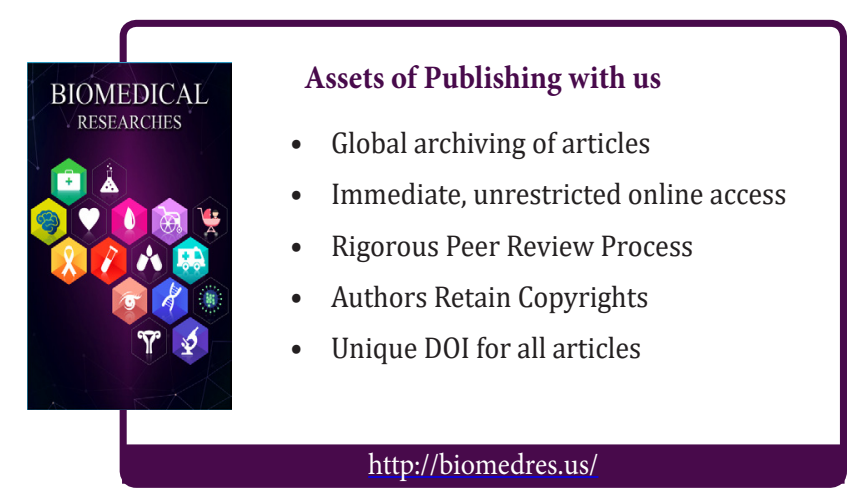

